\title{
Virgin queens in stingless bee (Apidae, Meliponinae) colonies: a review
}

\author{
VL Imperatriz-Fonseca ${ }^{1}, \mathrm{R}$ Zucchi 2 \\ 1 Departamento de Ecologia Geral, IBUSP, CP 11461, CEP 05422-970 São Paulo, SP; \\ 2 Setor de Ecologia da Faculdade de Filosofia, Ciências e Letras da USP, \\ CEP 14 300-000 Ribeirão Preto, SP, Brazil
}

(Received 9 December 1994; accepted 20 March 1995)

\begin{abstract}
Summary - There are no differences between Trigonini and Meliponini in terms of their treatment of virgin queens. They may stay in the nest, leave during swarm, supersede the dominant queen, or be killed, depending on what happens inside the colony. However, some kinds of behavior and strategies are characteristic of each species and part of its repertoire; examples are the onset of attractiveness, type of isolation, maturity, and the permanence of gynes in the colonies. Behavioral patterns are similar to all gynes. Attractive gynes have swollen abdomens, and abdominal glands are exposed during periods of attractiveness; they are very active, they run through the colony and search for trophallaxis. Natural polygyny occurs in Melipona bicolor, but needs additional studies to be well understood. Temporary oligogyny occurs during supersedure process in Plebeia. The control of the number of virgin queens during certain periods of time is suggested in Trigona (Trigona), acting on the gynes' emergence from royal cells or simultaneous metamorphosis of pupae. The presence of gynes in the nests stimulates swarm or supersedure. In these bees, one or more virgin queens depart with a swarm; fertilization occurs in a nuptial flight near the new nest. Swarm is a gradual process, with resource transportation from mother to daughter colonies. Supersedure may or may not be gradual. Attractive gynes, as well as workers, take active part in this process.
\end{abstract}

Meliponinae / stingless bees / gyne / queen supersedure / swarm

\section{INTRODUCTION}

Meliponinae, which are highly eusocial bees, constitute a very interesting and diversified group. Little is known about their reproductive strategies (Engels and Imperatriz-Fonseca, 1990). Massive provisioning of the brood cells entails the need to keep gynes (virgin queens) in the colony to ensure its perenniality if the dominant queen dies. It is assumed that stingless bee queens have pheromonal control over worker activities and physiology, as occurs in other similar eusocial species (Engels et al, 1987, 1993). Although the nature of such regulations is unknown, it probably differs from the closely related Apinae. The permanence of attractive gynes in the nests is a central point in 
stingless bees sociobiology. As stressed by Sakagami (1971), the socio-ethological make-up of both societies (Apinae and Meliponinae) suggests that their similar eusocial patterns were reached divergently.

The pattern of queen dominance presented by Apis mellifera and its effect on workers is normally used for comparative purposes. In this species, the queen controls the appearance of royal cells and also the activation of workers' ovaries (Pain, 1961; Free, 1987). In the Meliponinae, royal cells are constructed all the year round, and whether the queen has any influence on the construction of such cells is unknown. Moreover, the nurse-workers of most of the studied taxa have activated ovaries and produced eggs that are generally eaten by the queen. So, in such a taxon, if there is any control by the queen, it probably involves different pathways in comparison to Apinae. This mainly concerns the oviposition of workers that will yield males, after dominant queen oviposition and during the operculation of cells (Beig, 1972).

As regards the emerging virgin queens, they may be killed, supersede the dominant queen, or swarm to start a new nest with workers. All 3 possibilities occur in different episodes of the colonial cycle. Several factors certainly influence these events, of which the respective promoters have not yet been identified.

This paper presents a review of the virgin queen's behavior and permanence in stingless bee nests. Most of the reproductive aspects dealt with here are only factual and derive from unplanned events that took place in the course of several experiments and observations. This indicates the character of this paper, which mainly intends to report facts that are not normally delivered in formal publications on account of their incidental occurrence. The generic citations throughout the text follow the classificatory system devised by Moure $(1951,1961)$ and Camargo and Pedro (1992).

\section{BEHAVIOUR OF VIRGIN QUEENS IN MELIPONINI}

The Meliponinae comprise 2 tribes: Meliponini, with a single genus, Melipona, and Trigonini, with several genera (Moure, 1961). The larger royal cells of the Trigonini distinguish them from the Meliponini, whose queens, males and workers are bred in identical cells.

In Meliponini, castes are determined by the interaction of genes with the environment (Kerr et al, 1966; Velthuis and Sommeijer, 1991). Virgin queens are smaller than workers, they emerge all the year round, and are usually killed by workers. In Melipona, queens have similar characteristics in their behavioral repertoire; they have a shorter ontogeny than workers (data for $M$ marginata and $M$ quadrifasciata), and normally emerge without attractiveness, ie they do not release specific responses in workers. At the onset of attractivity they move more quickly around the nest, requesting food from workers by making contact with their antennae aided by their front legs. This is the stage at which pheromone production probably starts. Attractive queens generally keep their abdomen swollen and appear larger. They actively seek the area where the new comb is being built, particularly during the cell provisioning and oviposition process, and may possibly ingest alimentary eggs laid by workers (Silva et al, 1972; Kleinert-Giovannini, 1989). At the peak of their attractiveness, they expose their swollen abdomen to the majority of the surrounding workers, through circular movements. Such gynes may then be killed or accepted. When the gyne is accepted, she helps workers eliminate the other virgin queens.

In normal colonies, the attractiveness of the virgin queens causes an agonistic attitude among workers who start chasing and killing them by twisting off their heads and other body parts. Such remains are placed in the refuse area and removed from the 
colony. This is the fate of most Melipona queens. $M$ marginata, however, sometimes preserves a larger number of queens inside the colony (Kleinert and Imperatriz-Fonseca, 1994). They take refuge in common areas, such as parts of the exoinvolucrum, remaining there for hours. From the body posture of the virgin queens, and the trophallaxis that occurs, it can be assumed that there is an hierarchy among them. Therefore, in this case, several queens are protected as a group by a physical barrier.

Mota studied the development of abdominal glands in Melipona queens (Mota, 1982, 1988; Cruz-Landim and Mota, 1990). The presence and development of these glands may explain why the virgin queen rubs the tip of her enlarged abdomen on the workers' head; this has been observed in $M$ quadrifasciata and $M$ marginata at the peak of her attractiveness. This might also explain the apparently defensive mechanism used by the virgin queen of $M$ quinquefasciata, who spins around at high speed, hitting workers with her abdomen and tossing them into the distance. While this is occurring, the intersegmental membranes of the virgin queen's abdomen are exposed, and whenever possible this region is pressed against the workers' heads (Zucchi, 1977). Regarding the natural supersedure of queens in Melipona, Silva et al (1972) described the process for M quadrifasciata and $M$ quinquefasciata. In the phase preceding supersedure there are many virgin queens, one of whom occupies an outstanding position even before the dominant queen is eliminated. If virgin queens continue to emerge, the possibility of choosing a new queen is present. Kleinert-Giovannini (1989) observed that the supersedure in Melipona marginata starts taking place when the queen's productivity is low. Silva et al (1972) made similar observations regarding $M$ quadrifasciata and $M$ quinquefasciata and highlighted other disorders on these occasions, affecting provisioning and laying of eggs in brood cells.
$M$ bicolor presents a natural polygyny. The term polygyny is used here in the same way as Herbers (1993) did: "to denote the peaceful coexistence of 2 or more mated egg-layers (queens) in the same nest,....and the intermixing of their offspring within one socially homogeneous unit". Colonies of $M$ bicolor with large populations may have as many as 5 physogastric queens simultaneously involved in oviposition, apparently without any agonistic behavior (Bego, 1983, 1988, 1989). There are even situations in which 1 queen remains to attend to the cell where the larval food is being placed, while another approaches and lays. Although dominance among queens is likely, conflicts are suggested by the male production by the workers, which is conspicuous than in polygynic nests, and the length of the interval between oviposition by the queen and cell operculation by the workers. Other behaviors that differ are related to the kind of courtship that workers pay to the queens, with pronounced antennal contact and a long duration.

Unlike those of other known stingless bees, dominant queens of $M$ bicolor rarely beat their wings, which thus do not wear out as they become older (Bego, 1988). A dominant queen may live as long as 7 years (Drumond, personal communication). Most colonies kept in laboratories are monogynous. Observations showed increased queen numbers under laboratory conditions in colonies provided with extra food. One of these colonies had 2 physogastric queens, 1 of which laid most of the eggs. $A$ third virgin queen was selected and mated. When the new queen began laying, her abdomen was very small and similar to that of an attractive virgin queen. For a few days only this newly fertilized queen preferably participated in the arousal phase and oviposited in cells. Later on the dominant physogastric queen began ovipositing more frequently, although both occasionally took part in stimulating the oviposition process. 
The polygyny needs further experimental studies to be better understood.

Kleinert-Giovannini (1989) used an experimental technique to promote a polygynic status, by adding a second physogastric queen to normal colonies of $M$ marginata. For some time, both queens remained alive and ovipositing. It was possible to study the conflict of interests of both queens and their progenies, taking into account the degree of relatedness among queens and the health of their nests (Kleinert-Giovaninni, 1990). Andrade and Kerr (1990) also changed queens among $M$ compressipes colonies, adding a second physogastric queen in experimenting with other colonies.

Melipona queens are fertilized by a single male (Kerr et al, 1962; Camargo, 1972 , 1984; Silva et al, 1972; Page and Kerr, 1990). In M quadrifasciata and $M$ quinquefasciata there is evidence of queens making nuptial flights when they are 3 to 8 days old. Nuptial flights were long, lasting 33-102 min (Silva et al, 1972). There is no evidence of males aggregating close to the entrance of the Melipona colonies when a queen needs to mate. Sommeijer (1994) verified that queens of $M$ favosa fly until a non-nest drone congregation area that is formed in the neighborhood of the colony by approximately 400 drones originated from different nests.

After the nuptial flight, parts of the male's genitals remain stuck to those of the female. This is called the mating sign (Kerr and Krause, 1950; Silva et al, 1972). Occasionally, when the hive is being handled, the physogastric queen may mate again (Campos and Melo, 1990), but this is an unusual situation and reflects abnormal condition.

\section{BEHAVIOUR OF VIRGIN QUEENS IN TRIGONINI}

In Trigonini, queens are usually larger than workers. They also have a longer ontogeny than workers, and older royal cells can therefore be found in the involucrum, supported by bars of cerumen, since the original comb in which they were has been dismantled. Some of these cells give rise to giant males (Nogueira-Neto, 1951; Juliani, 1967; Imperatriz, 1970; Imperatriz-Fonseca et al, 1975; Silva, 1977; Cortopassi-Laurino, 1978; Bego and Camargo, 1984). Royal cells may very occasionally produce giant workers (Oliveira and Imperatriz-Fonseca, 1973).

Royal cells are usually built at the edge of combs. They have the same shape as ordinary cells, but in Paratrigona subnuda there are 2 royal cell architectures: 1 is bottleshaped and the other normal. They are sometimes found side by side. Royal cells are sometimes built in the center of the comb.

The number of royal cells built varies from 1 species to another, and within the same species it is influenced by many factors. Under favorable conditions, several colonies will often build royal cells at the same time. Biotic and abiotic conditions will together act to determine the fate of virgin queens. In subtropical environments, an increase of construction of royal cell occurs in autumn, for instance, in Plebeia remota (Van Benthen et al, 1995). Besides the environmental factors, the biotic factors that seem to be important include the physiological state of the queen, the population size of the colony and the amount of stored food.

Most stingless bees produce castes under similar ontogenetic periods. However, in some Trigona, the development period of the queens is much longer and, as a consequence, their nests generally show many such cells scattered around the brood chambers, well apart from the remaining combs. In a given nest of Trigona crassipes, 132 queen cells were found (Camargo and Roubik, 1991). This normally happens because, although queen cells are always built at the edge of fully grown fresh combs, 
their delayed development means that they remain long after the emergence of their synchronously produced sister-workers (Sakagami, 1982; Camargo and Roubik, 1991). This is probably the outcome of 2 characteristics: post-defecating queen larvae apparently remain at a quiescent stage for long periods (maximum observed time, 11 months in $T$ hypogea); and the fully developed queen remains in the royal cell for another variable but normally long period before emergence. Indeed, in some cases, if the cell membrane is torn apart, the fully pigmented queen moves around quickly and can even fly. These adaptations increase considerably the number of gynes available and can make an eventual supersedure process less hazardous than usual. Moreover, Trigona bees usually make very large nests and their queens normally have an increased number of ovarioles (10-15) per ovary.

In some Trigonini, royal cells are rarely seen in the nest. Among these, Leurotrigona mülleri and Frieseomelitta varia are of special interest since they are capable of breeding queens in 2 different ways. One is the classic method, ie by building royal cells. However, Terada (1974) found that in these bees royal cells may originate by superfeeding some of the larvae. They then perforate the wall of a neighboring cell and consume the food it contains. The prepupa can then enlarge its cell to the size of a royal cell. This system evidences a different method for producing queens compared with the other stingless bees studied to date.

Other stingless bees regularly produce queens of different sizes, eg, Schwarziana quadripunctata. One characteristic distinguishing this Trigonini species from others is the regular emergence of queens of varying sizes throughout the year. Camargo (1974) remarked that combs with pupae point to the presence of larger cells in an irregular spatial arrangement, which give rise to queens. Some of these queens are exactly the same size as the workers or smaller and can be termed miniature queens (fig 1). These categories of queens have different numbers of ovarioles (Camargo, 1974). The combs contain cells with slightly larger pupae which produce medium-sized queens, as well as a few large royal cells, which produce large queens or giant males. In 2 years of recording the cells being built by a colony of these bees, only 1 cell being constructed was slightly larger than normal. An additional factor that makes this discussion harder is that the size of workers may also vary, mainly according to colonial conditions. When virgin queens are emerging, there may be as many as $30-40$ queens simultaneously.

Except in the case of $S$ quadripunctata, normal colonies do not usually contain miniature queens, ie queens of Trigonini reared in cells normally built for males and workers. There are references to these miniature queens in the literature (Cephalotrigona femorata, Nogueira-Neto, 1951; $P$ juliani, Juliani, 1962; $P$ remota, Imperatriz-Fonseca et al, 1975; $P$ emerina, Kleinert (personal communication); $P$ droryana, $P$ remota and Nannotrigona testaceicornis, Imperatriz-Fonseca et al, unpublished data). In the case of $N$ testaceicornis, 7 miniature queens were found in a comb

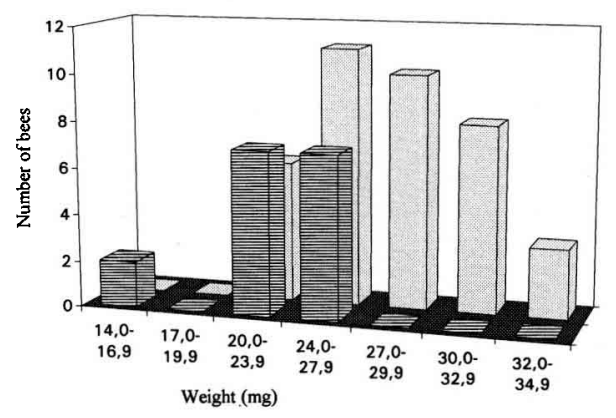

Fig 1. Weight of workers and gynes in Schwarziana quadripunctata. Worker; 冒 virgin queen. 
also containing a normal royal cell; the colony was swarming. In this case it was possible to observe the behavior of these queens, which did not differ from that of normal queens (Imperatriz-Fonseca et al, unpublished data). Lucio de Oliveira Campos also found 5 of these queens simultaneously in $N$ testaceicornis. These facts constitute a challenge to the theories of caste determination in Trigonini.

There are differences among species (and also variations are found intraspecifically) in terms of the activities of virgin queens from the moment of emergence. In some species, most of queens are born unattractive and non-pigmented (eg, Scaptotrigona, Paratrigona, Schwarziana and Nannotrigona), while in others they are born attractive (Plebeia, Frieseomelitta, Tetragonula, Meliponula and Friesella). Emerging attractive means causing changes in the intranidal behavior, which may even alter the process of brood cell construction, triggering specific worker responses, moving quickly through the entire hive with abundant abdominal movements, and seeking for trophallaxis with workers. In exceptional cases, the queen may be so attractive at this time that she may supersede the dominant queen in the nest ( $P$ remota). Being born unattractive means not causing any worker response at all.

Queens that emerge attractive alter the behavior of the colony. According to Van Benthem et al (1995), $P$ remota queens are always attractive at emergence, and most were killed in a few hours after emergence by workers. Those left alive can be 'enclosed' and kept alive in cerumen chambers, protected by a physical barrier of wax, or a royal chamber, originally termed a 'prison' (Moure et al, 1958; Nogueira-Neto, 1958). 'Prisons' have been observed in $P$ remota, $P$ juliani, $P$ emerina, $P$ droryana, $F$ varia, $F$ silvestrii, $F$ languida, Tetragonisca angustula, Friesella schrottkyi and Scaura latitarsis. Nevertheless, the gynes them- selves can open or close the royal chambers, allowing some workers to enter or leave them. The name prison could give the idea of an area under complete worker control, which is a misunderstanding of the phenomenon of a protected individual territory.

A different strategy has been observed in $C$ longicornis and $L$ mülleri (Terada, 1974). In these bees, the virgin queen is constantly surrounded by a court of workers, who form a kind of barrier by preventing her from moving outside the center of the ring in which she is confined. Workers forming this living barrier prevent any aggressions to the queen. Sometimes the territorial limits are crossed. The virgin queen breaks out, followed by many workers and creating general havoc. She may then be killed or once more 'trapped' in a circle of workers. In this case, a mobile territory for gyne is created.

When protected by a royal chamber, the virgin queen can generally communicate with the outside through an orifice. She can be fed by workers, who may enter and leave through the cell hole, probably transmitting information about pheromones eliminated in the neighborhood. The gyne controls this opening, as well as the presence of workers inside it (Imperatriz-Fonseca et al, 1975). The duration of closure varies considerably, from days to months. More than 1 royal chamber in 1 colony has been observed at the same time in Plebeia and Schwarziana (Juliani, 1962; Imperatriz-Fonseca, 1990). Cortopassi-Laurino (1978) observed the behavior of virgin queens in $P$ droryana. In this case, the prison, which was initially built with thin walls, was almost always surrounded by workers, who deposited pure wax outside the chamber, which gradually took on quite a different shape. Initially, the chamber was often closed. After some time, it remained opened most of the time so as to enable the virgin queen to leave it, move around the colony and return, until maturity was reached. This kind of behavior was not 
observed in a long study of colonies of $P$ remota, for example. Isolation of the gynes occurred shortly after emergence of attractive queens in $P$ remota, $P$ droryana, $P$ emerina, $P$ juliani, $F$ varia, $F$ languida, $P$ (Friesella) schrottkyi and $S$ latitarsis, and as soon as attractiveness is manifest in $S$ quadripunctata. Several chambers built side by side on the same day, with partially common walls, were observed in $S$ quadripunctata, for queens of intermediate size (Imperatriz-Fonseca, 1990). They were destroyed one by one on the same day, leaving one intact. The internal conditions of the colony which favor construction of royal chambers in Schwarziana have not been clarified. On some occasions, we have observed chambers being built by mediumsize pigmented queens, without causing any worker response. Queens may remain in these chambers for a few days, leave and build other chambers in the involucrum. Some form of homeostasis causes these queens to be tolerated, without provoking any specific worker responses.

Depending on the state of the colony at the time when the virgin queen becomes attractive, the royal chamber may be built by the workers or by the queen herself ( $F$ schrottkyi, $F$ varia, Flanguida, S quadripunctata, $P$ droryana and $P$ remota). Construction by the queen involves the same gyrating abdominal movements mentioned above for $M$ quinquefasciata, with small pieces of cerumen being torn away from nearby walls so as to delimit a circle or ring. Workers may provide assistance later on.

Virgin queens who emerge unattractive, usually with little pigmentation (Nannotrigona, Schwarziana, Paratrigona and Scaptotrigona), initially remain close to the comb, as do newly emerged workers, and are not molested by older workers. They move freely about in the colony until they begin to be attractive.

When virgin queens of $P$ subnuda become attractive, their tergal and mandibu- lar glands develop (Cruz-Landim et al, 1980) and they maintain trophallactic and antennal contacts with workers. As soon as these glandular products run out, they take refuge in empty food pots, which they seal up using their mandibles. The period of isolation in these pots varies considerably. It can be a few minutes or several hours, during which they remain alone or may be accompanied by workers. Before leaving the refuge they thrust their antennae outside the pot, probably to obtain information about the external situation. Presumably, when they have replenished their glands with new substances, they voluntarily leave the pot and circulate through the colony, seeking trophallaxis, and returning to the refuge whenever necessary. The refuge is not fixed for the use of 1 particular gyne, but can be used by more than 1 queen consecutively. This process leads to a peak of attractiveness, probably when the virgin queen completes glandular development to the secretion of pheromone. She then tries to supersede the queen of the colony (Imperatriz-Fonseca, 1977). Thus the virgin queen usually continues her development in the colony until she reaches maturity, passing through specific glandular changes and being recognized by a certain number of workers through physical contacts. Workers may be progressively recruited and several virgin queens may be simultaneously active in the same colony. In the case of imprisoned queens (Plebeia, Friesella and Tetragonisca), pheromones are probably concentrated in the surrounding structure, which is manipulated regularly by the gyne. In the case of gynes who move around, they presumably concentrate these substances in their own glands and spread them in trophallaxis and droppings.

Hebling et al (1964) observed a virgin queen of Scaptotrigona xanthotricha who was kept in the colony for $32 \mathrm{~d}$ and then killed in $17 \mathrm{~min}$, after a sudden attack by workers. Although Scaptotrigona is one of 
the most intensely studied genera of stingless bees, there are few data about the biology of its virgin queens (Engels and Imperatriz-Fonseca, 1990).

Regardless of the strategy pursued, the virgin queen must be duly recognized by workers, as is the case in other eusocial bees. Supersedure of the dominant queen at varying intervals ensures the perenniality of the colony. This process was observed in $P$ subnuda (Imperatriz-Fonseca, 1977), $P$ droryana (Silva, 1972), $P$ remota (Van Benthem and Imperatriz-Fonseca, unpublished data), $P$ wittmannii (Freitas, 1994) and $F$ languida (Ribeiro, 1989). Attempts to supersede the queen in Paratrigona, mark the end of the process by which the virgin queen reaches maturity, with fully developed mandibular glands. After reaching a peak of attractiveness, the virgin queen deposits drops of mandibular, and sometimes fecal, substances on the body of the dominant queen, which is then intensely licked by workers, and is courted by an unusually large number of individuals. After depositing her substances, the virgin queen continues to seek trophallaxis and contacts with workers, and deposits drops on the other queen's body from time to time. The laying queen does not defend herself. Licking the physogastric queen's body, workers can evaluate which of the 2 queens has the greater power of attraction. One of them will then be killed.

In the case of $P$ droryana (Silva, 1972) and $P$ wittmanni (Freitas, 1994), a new queen may be chosen and mated so as to supersede while the old queen is still active in egg laying. Both will coexist for a time, and both oviposit over a few days. Freitas (1994) observed the change of queen attractiveness by comparing the number of cells oviposited by each queen in a batch of cells, until the new queen eliminated the other by attacking her bodily. Workers then killed the old queen. Imperatriz-Fonseca (1973) found 2 physogastric queens in a colony of $S$ quadripunctata, but only 1 of them oviposited. Camargo and Moure (1994) also found 2 physogastric queens in Apotrigona impunctata, but did not mention their behavioral conditions.

In $P$ remota, the natural supersedure observed by Van Benthem et al (1995) occurred in a strong colony immediately after emergence of the virgin queen and by the latter's initiative, when she successively attacked the dominant queen until death. After this process, however, she roamed freely through the colony, passing through the stages of contact with workers, and only a few days later making the nuptial flight and resuming egg laying.

In F languida, Ribeiro (1989) verified that when the gyne superseded the queen, she also attacked and was helped by workers that kept the physogastric queen immobile. After having been chosen by the colony, the gynes help to eliminate the queen. During the supersedure process, which is not always successful for the gyne, yellowish mandibular or fecal substances are often liberated on the comb, or elsewhere in the colony (Simões, 1974; Imperatriz-Fonseca, 1977; Simões and Bego, 1979; Bego, 1989; Ribeiro, 1989).

\section{VIRGIN QUEENS AND SWARMS}

To depart with a swarm is another possibility for the gynes that are kept alive in the nest. This unpredictable occurrence was not generally observed within the few stingless bees species that have been studied up to now. Hockings (1884) was the first to notice the participation of virgin queens in the stingless bee swarm, instead of the dominant queen, as in Apis. Peckolt (1894) thought that virgin queens should guide and find new nests with workers. Nogueira-Neto (1954) later pointed out that colony reproduction in Meliponinae is a gradual phenomenon, reporting to the long link between 
the mother and daughter colony in this process. He also mentioned the gynes' arrival at the new nest. Kerr et al (1962) revealed that the $S$ postica virgin queen arrived at the new nest $5 d$ after the beginning of the process of nest construction. Sometimes, more than one gyne moves to the new nest where fertilization occurs. Michener (1946) mentioned the beginning of a new nest of a jaty, including the male swarm at its entrance. Ferreira (1994) studied $T$ angust$u / a$ and verified that those males arrived to the daughter nest entrance earlier than the swarm did; this suggests a volatile attractive substance produced by the workers in the new nest.

Terada (1974) observed the mother and the daughter nest of $F$ varia and gave a wider view of swarm activity. In the mother nest, an imprisoned virgin queen was accepted by the workers; the mother nest entrance was enlarged and cerumen transportation between colonies began. This gyne left the royal chamber $1 \mathrm{~h}$ before swarm departure and arrived in the new nest, $50 \mathrm{~m}$ away, after $30 \mathrm{~s}$, accompanied by workers of different ages, including some newly emerged. In this case, males arrived at the new nest entrance $5 \mathrm{~d}$ later.

Darchen (1977) observed the swarm in 22 nests of Hypotrigona. He also verified the arrival of virgin queen encircled by workers of several ages. Clouds of males were observed in front of the new nests. The gynes fertilization occurred after $48 \mathrm{~h}$. The entrance, in this case a kind of excluder for queens, was completed after the fertilization of the gyne.

Inoue et al (1984a) studied a swarm in $T$ (Tetragonula) laeviceps. This is a very rapid process, where daughter colony is independent of mother colony 1 week after the arrival of the virgin queen. Most of the males remained at the nest entrance for $2 \mathrm{~d}$ after arrival of the gyne. The behavior of gynes in the daughter nest is mentioned before the beginning of egg laying. The attractiveness of gynes changes after mating. According to Engels and Engels (1988) and Engels et al (1993), virgin queens of $S$ postica present different patterns of agedependent pheromone composition; this can be a rule for stingless bees.

Imperatriz-Fonseca (1975) observed swarming departure in $P$ subnuda. In this case, it occurred on the same day of the beginning of cerumen transportation from mother to daughter nests. The gynes were very active. The most active searched for trophallaxis with the workers who carried loads of cerumen to the new nest and left accompanied by them and by males; 2 other gynes also left the nest. This departure was very fast, and there was no cloud of males in front of the mother nest. The daughter nest was not found.

Finally, it is interesting to mention another swarm departure observed in S tubiba. A swarm left the nest and stopped near the mother nest for $2 \mathrm{~d}$, similar to what occurs in Apis. This possibility of another kind of swarm, as well as absconding (Inoue et al, $1984 b$ ) within stingless bees, should be considered.

Behavioral variability is expected in large bee families such as Meliponinae. This survey indicates some trends. Fluctuations in population size and ecological pressures will entail a plasticity of solutions for the same problem: the increase in the production of sexuals to assure the colony perenniality.

\section{ACKNOWLEDGMENT}

The authors thank to $W$ Engels for his comments and helpful suggestions.

Résumé - Les reines vierges dans les colonies d'abeilles sans dard (Apidae, Meliponinae) : mise au point. II existe plusieurs stratégies pour maintenir les reines chez les espèces d'abeilles sans dard. Elles 
incluent toutes une protection des reines vierges, au moins durant certaines périodes du cycle de la colonie. Chez les Meliponini, où les reines émergent et sont tuées en grand nombre tout au long de l'année, it existe des possibilités pour survivre plus longtemps dans le nid: les reines se réfugient dans des endroits déterminés utilisés en commun. Chez ces reines, on peut déceler des niveaux de hiérarchie. Schwarziana quadripunctata présente une autre forme de coexistence des reines, grâce à une plasticité du répertoire comportemental qui va de la protection des reines dans des chambres royales individuelles à une totale indifférence à leur présence dans le nid. Chez Nannotrigona et Scaptotrigona on trouve des reines en nombre réduit circulant librement dans le nid. L'étape suivante est représentée par Paratrigona subnuda, chez qui les reines utilisent des pots à miel vides comme refuges temporaires. Ces pots peuvent être visités par plus d'une reine dans la même journée, ce qui prouve que la protection de la reine n'est due qu'à une barrière physique; dans ce cas les reines circulent librement dans le nid pendant certaines périodes à la recherche d'échanges trophallactiques. Un caractère commun à toutes les reines dont il a été question jusqu'à présent est leur mobilité dans le nid. Celetrigona longicornis et Leurotrigona mulleri présentent l'étape suivante, où les reines sont constamment entourées par une cour d'ouvrières. Elles se déplacent ensemble dans le nid mais restent généralement à distance de la reine fécondée et des rayons à couvain. Chez de nombreuses espèces (Plebeia, Friesomellita) les reines sont maintenues dans des zones déterminées, les chambres royales, pendant une période de temps variable. Dans ce cas, ce n'est qu'après un signal spécial issu du milieu, apporté par les ouvrières ou par l'intermédiaire des phéromones de la colonie, que la reine quitte la chambre royale et circule librement dans la colonie pour tenter de remplacer la reine ou de partir avec un essaim. La colonie peut contrôler l'apparition simultanée de nombreuses reines même chez les espèces qui construisent continuellement des cellules royales. Par exemple, chez Trigona hypogea, les reines peuvent rester jusqu'à 11 mois dans leur cellule royale au stade de nymphe et terminer ensemble leur cycle de développement quand un signal spécial est donné par la colonie. Chez Trigona recursa, les reines prêtes n'émergent pas de leur cellule royale élargie, mais y restent pendant une longue période au cours de laquelle elles consomment les réserves de leur corps pour survivre. Quant au changement de la reine dominante (supersédure), les tentatives des reines vierges pour éliminer la reine en place sont fréquentes mais souvent infructueuses. La supersédure est généralement réalisée par les reines matures, mais elle peut être tentée par une reine fraîchement éclose, particulièrement attractive. Un remplacement graduel semble commun chez les espèces de Plebeia. Dans ce cas la reine est choisie ; après s'être accouplée, elle commence à pondre tandis que la vieille reine physogastre est toujours en vie et continue de pondre. Les comportements qui dénotent une très forte attraction des reines vierges sont les mêmes chez les espèces étudiées : elles offrent aux ouvrières qui entourent la reine attractive un abdomen gonflé, recherchent les échanges trophallactiques avec les ouvrières et parfois délivrent une goutte d'une substance jaunâtre au cours de la trophallaxie. Le comportement le plus frappant pendant la supersédure a été observé chez Paratrigona subnuda, chez qui la jeune reine attractive répand sur le corps de la vieille reine des substances dont les caractéristiques déterminent le déroulement du processus de remplacement. Les ouvrières participent aussi aux tentatives de supersédure en protégeant ou en attaquant la reine. Dans le nid et dans les conditions de milieu particulières les reines vierges attractives peuvent favoriser la division de la colonie par 
un essaimage graduel : l'emplacement du nouveau nid est choisi, préparé et reçoit une ou plusieurs reines vierges accompagnées d'ouvrières d'âge varié. Le cérumen, la cire et la propolis proviennent de la colonie mère. La reine sera fécondée lors de son vol vers le nouveau nid où, chez les Trigonini, l'attend généralement un nuage de mâles. Chez les Meliponini, les données concernant Melipona favosa montrent que les reines vierges sélectionnées volent jusqu'à un lieu de rassemblement de mâles situé près du nid. Les 2 colonies, mère et fille, communiquent pendant une certaine période par l'intermédiaire de l'activité des ouvrières.

\section{Meliponinae / reine / supersédure / essai- mage / régulation sociale}

\section{Zusammenfassung - Unbegattete Köni- ginnen in Völkern der stachellosen Bie- nen (Apidae, Meliponinae): Ein Überblick.} Es gibt mehrere Strategien innerhalb der stachellosen Bienenarten, wie weibliche Geschlechtstiere im Volk behandelt werden. Bei allen Arten gibt es zumindest während einer begrenzten Zeitspanne innerhalb des Volkszyklus einen Schutz für unbegattete Königinnen. Bei Meliponinen schlüpfen Geschlechtstiere während des ganzen Jahres. Eine große Zahl wird getötet, aber es besteht auch die Möglichkeit, für eine längere Zeit im Nest zu überleben. Dazu ziehen sich die Königinnen auf bestimmte, gemeinsam genutzte Plätze zurück. In diesen Fällen läßt sich eine hierarchische Rangordnung zwischen den Königinnen beobachten. Eine andere Form der Koexistenz ist bei Schwarziana quadripunctata verwirklicht. Dort gibt es vielfältige Verhaltensmuster, die vom Königinnenschutz in individuellen 'Königinnenkammern' bis zu einer vollständigen Gleichgültigkeit gegenüber ihrer Anwesenheit im Volk reichen. Bei Nannotrigona und Scaptotrigona bewegen sich die Königinnen in verringerter Anzahl frei im Volk. Der nächste Schritt kann am Beispiel von Paratrigona subnuda gezeigt werden: Königinnen benutzen leere Honigtöpfe als zeitweises Versteck. Diese Töpfe können von mehreren Königinnen an demselben Tag benutzt werden, was darauf hinweist, daß der Schutz nur eine physikalische Barriere ist. Außerdem laufen die Königinnen bei dieser Art für bestimmte Zeitspannen frei im Volk auf der Suche nach Futteraustausch (Trophallaxis). Die gemeinsame Eigenschaft aller bisher besprochenen Fälle ist, daß sich die Königinnen im Nest frei bewegen können. Ein nächster Schritt ist bei den Arten verwirklicht, bei denen die Königinnen ständig von einem Hofstaat von Arbeiterinnen umgeben sind (Celetrigona longicornis and Leurotrigona mulleri). Sie laufen gemeinsam im Nest, halten aber im allgemeinen Abstand von der begatteten Königin und den Brutwaben. Bei vielen Arten (Plebeia, Frieseomellita) werden junge Königinnen in bestimmten Territorien, den 'Königinnenkammern', über unterschiedlich lange Zeiten gehalten. In diesen Fällen verlassen die Königinnen erst nach bestimmten Umweltreizen, die durch die Arbeiterinnen oder Pheromone übertragen werden, ihre Zellen. Dann zirkulieren sie durch das Volk und versuchen, die alte Königin abzulösen oder mit einem Schwarm das Nest zu verlassen. Eine Kontrolle über das simultane Auftreten mehrerer Königinnen durch das Volk kommt auch bei Arten vor, die fortwährend Königinnenzellen bauen. Bei Trigona hypogea zB können Königinnen bis zu 11 Monaten als Puppen in den Zellen verharren, um dann auf einen speziellen Reiz hin simultan zu schlüpfen. Bei Trigona recursa schlüpfen die fertigen Königinnen nicht aus ihren großen Königinnenzellen, sondern verbleiben dort für lange Zeit, wobei sie von ihren körpereigenen Reservesubstanzen leben. Die unbegatteten Königinnen versuchen zwar häufig, die dominante Königin im Volk abzulösen, dies ist aber meist vergeblich. Der Königinnenwechsel erfolgt überwiegend durch reife 
Königinnen, jedoch manchmal versucht es auch eine besonders attraktive frisch geschlüpfte Königin. Ein gradueller Ersatz der alten Königin ist bei Plebeia Arten verbreitet. In diesen Fällen wird eine neue Königin ausgewählt. Nach ihrer Begattung beginnt sie mit der Eiablage, während die alte physogastrische Königin noch lebt und Eier legt. Die Verhaltensweisen von unbegatteten besonders attraktiven Königinnen sind bei allen beobachteten Arten gleich: Arbeiterinnen, die die attraktive Königin umringen, wird der geschwollene Hinterleib geboten, Arbeiterinnen werden zum Futteraustausch angebettelt und manchmal wird ein Tropfen gelblicher Substanz bei dieser Trophallaxis abgegeben. Das auffälligste Verhalten während des Königinnentausches wurde bei Paratrigona subnuda beobachtet, bei der von einer jungen attraktiven Königin Substanzen auf den Körper der alten Königin abgegeben wurden, deren Eigenschaften den weiteren Verlauf des Ablösungsprozesses bestimmen. Arbeiterinnen sind an den Austauschversuchen beteiligt, indem sie entweder die alte Königin schützen oder angreifen. Junge attraktive Königinnen im Nest können unter speziellen Umweltbedingungen die Teilung eines Volkes fördern. Dies erfolgt durch graduelles Schwärmen: zunächst wird ein Nistplatz gesucht und vorbereitet, dann ziehen ein oder mehrere unbegattete Königinnen zusammen mit einigen verschieden alten Arbeiterinnen dorthin. Cerumen, Wachs und Propolis stammen aus dem Mutternest. Die Königinnen verlassen zur Paarung das neue Nest, wo bei Trigonini normalerweise Wolken von Drohnen vor dem Nesteingang auf sie warten. Bei den Meliponini zeigen Beobachtungen von Melipona favosa, daß auserwählte Königinnen zu Drohnensammelplätzen fliegen, die sich in der Nähe des Nestes befinden. Die Mütter- und Töchtervölker bleiben durch die Aktivitäten der Arbeiterinnen über einige Zeit in Kontakt.

\section{Meliponinae / Königinnentausch / Schwärmen / soziale Regulation}

\section{REFERENCES}

Andrade CM, Kerr WE (1990) Experimental exchange of queens between colonies of Melipona compressipes (Apidae, Meliponinae). Rev Bras Biol 50, 975-981

Beig D (1972) The production of males in queenright colonies of Trigona postica. J Apic Res 11, 33-39

Bego LR (1983) On some aspects of bionomics in Melipona bicolor bicolor Lepeletier (Hymenoptera, Apidae, Meliponinae). Rev Bras Entomol 27, 211224

Bego L (1988) Padrão geral de ovoposição em Melipona bicolor bicolor Lep (Hym, Meliponinae). Ciênc Cult 40, 920-921

Bego LR (1989) Behavioral interactions among queens of the polygynic stingless bee Melipona bicolor bicolor. Brazilian J Med Biol Res 22, 587-596

Bego LR, Camargo CA (1984) The occurrence of giant males in Nannotrigona (Scaptotrigona) postica Latreille (Hymenoptera, Meliponinae). Bol Zool Univ $S$ Paulo 8, 11-16

Camargo CA (1972) Mating of the social bee Melipona quadrifasciata under controlled conditions (Hymenoptera, Apidae). J Kans Entomol Soc 45, 520-523

Camargo CA (1984) Spermatozoa numbers and migration to the seminal vesicles in haploid and diploid males of Melipona quadrifasciata Lep. J Apic Res 23, 15-17

Camargo JMF (1974) Notas sobre a morfologia e a biologia de Plebeia (Schwarziana) quadripunctata quadripunctata Hymenoptera, Apidae, Meliponinae). Stud Entomol 17, 433-470

Camargo JMF, Roubik D (1991) Systematics and bionomics of the apoid obligate necrophages: the Trigona hypogea group (Hymenoptera, Apoidea, Meliponinae). Biol J Linnean Soc 44, 13-39

Camargo JMF, Pedro SRM (1992) Systematics, phylogeny and biogeography of the Meliponinae (Hymenoptera, Apidae): a mini-review. Apidologie 23, 509-522

Camargo JMF, Moure JS (1994) Meliponinae Neotropicais: os gêneros Paratrigona Schwarz, 1938 e Aparatrigona Moure,1951 (Hymenoptera, Apidae). Arq Zool 32, 33-109

Campos LAO, Melo GAR (1990) Physogastric-queen mating in Melipona quadrifasciata. Rev Bras Genet 13, 491-500

Cortopassi-Laurino M (1978) Observações sobre atividades de machos de Plebeia droryana Friese 
(Hymenoptera, Apidae, Meliponinae). Rev Bras Ent 23, 177-191

Cruz-Landim C, Hofling MCA, Imperatriz-Fonseca VL (1980) Tergal and mandibular glands in queen of Paratrigona subnuda. Morphology and associated behavior. Naturalia 5, 121-133

Cruz-Landim C, Mota MHVB (1990) Occurrence of tegumentary glands in stingless bee (Hymenoptera, Apidae, Meliponinae). In: Social Insects and the Environment (GK Veeresh, B Mallik, CA Viraktamah, eds), Oxford \& IBH Publishing Co, Bombay, India, 587

Darchen R (1977) L'essaimage chez les Hypotrogones au Gabon: dynamique de quelques populations. Apidologie 8, 33-59

Engels E, Engels W, Francke W (1987) Do stingless bees have two complexes of queen substances? In: Chemistry and Biology of Social Insects (Eder J, Rembold H, eds), Verlag Peperny, Munich, Germany, 710-711

Engels E, Engels W (1988) Age-dependent queen attractiveness for drones and mating in the stingless bee, Scaptotrigona postica. J Apic Res 27, 3-8

Engels W, Imperatriz-Fonseca VL (1990) Caste development, reproductive strategies and control of fertility in honey bees and stingless bees. In: Social Insects: An Evolutionary Approach to Caste and Reproduction (W Engels, ed), Springer Verlag, Heidelberg, Germany

Engels $E$, Engels W, Lübke G, Schröder W, Francke W (1993) Age-related patterns of volatile cephalic constituents in queens of the neotropical stingless bee Scaptotrigona postica Latr (Hymenoptera, Apidae). Apidologie 24, 539-548

Ferreira FHN (1993) Aspectos da estratégia reprodutiva em Tetragonisca angustula angustula. MSc thesis, USP Ribeirão Preto, Brazil, $105 \mathrm{p}$

Free JB (1987) Pheromones of Social Bees. Chapmann \& Hall, London, UK

Freitas SW (1994) Polietismo etário entre operárias, oviposição e substituição em Plebeia wittmanni Moure \& Camargo, 1989 (Hymenoptera: Apidae, Meliponinae). MSc thesis, PUCRS, Brazil

Herbers JM (1993) Ecological determinants in queen number in ants. In: Queen Number and Sociality in Insects (L Keller, ed), Oxford Sci Publ, Oxford, UK, 262-293

Hebling NJ, Kerr WE, Kerr FS (1964) Divisão de trabalho entre operárias de Trigona (Scaptotrigona) xanthotrica Moure. Papeis Avulsos Zool 16, 115127

Hockings HJ (1884) Notes on two Australian species of Trigona. Trans Ent Soc 32, 149-157

Imperatriz VLM (1970) Aparecimento de supermachos em Friesella schrottkyi (Apoidea, Apidae, Meliponinae). Cienc Cult 22, 291
Imperatriz-Fonseca VL (1973) Miscellaneous observations on the behavior of Schwarziana quadripunctata (Hymenoptera, Apidae, Meliponinae). Biol Zool Biol Mar 30, 633-640

Imperatriz-Fonseca VL (1975) Estudos bionôminos sobre a rainha virgem de Paratrigona subnuda Moure (Apidae, Meliponinae). PhD thesis, IBUSP, Brazil

Imperatriz-Fonseca VL, Oliveira MAC, Iwama S (1975) Notas sobre o comportamento de rainhas virgens de Plebeia (Plebeia) remota Holmberg (Apidae, Meliponinae). Cienc Cult 27,665-669

Imperatriz-Fonseca VL (1977) Studies on Paratrigona subnuda. 2. Behaviour of the virgin queen. $\mathrm{Bol} \mathrm{ZoO}$ USP 2, 169-182

Imperatriz-Fonseca VL (1990) Swarming in Schwarziana quadripunctata. In: Social Insects and the environment (GK Veeresh, B Mallik, CA Viraktamath, eds), Oxford \& IBH Publ Co, Bombay, India, 744-745

Inoue T, Sakagami SF, Salmah S, Yamane S (1984a) The process of colony multiplication un the Sumatran stingless bee Trigona (Tetragonula) laeviceps. Biotropica 16, 100-111

Inoue T, Sakagami SF, Salmah S, Nukmal N (1984b) Discovery of successful absconding in the stingless bee Trigona (Tetragonula) laeviceps. J Apic Res 23, $136-142$

Juliani $L$ (1962) $O$ aprisionamento de rainhas virgens em Trigonini. Bol Univ Paraná Zool 20, 1-11

Juliani $L$ (1967) A descrição do ninho e alguns dados biológicos sobre a abelha Plebeia juliani. Rev Bras Ent 12, 31-58

Kerr WE, Krause W (1950) Contribuição para o conhecimento da bionomia dos Meliponini. Fecundaç_o da rainha em Melipona quadrifasciata. Dusenia 1, 275-282

Kerr WE, Stort AC, Montenegro MJ (1966) Importância de alguns fatores ambientais na determinação das castas do gênero Melipona. Ann Acad Bras Cienc $38,149-168$

Kerr WE, Zucchi R, Nakadaira JT, Butolo JE (1962) Reproduction in the social bees (Hymenoptera, Apidae). J New York Entomol Soc 70, 265-276

Kleinert-Giovannini A (1989) Mecanismos de controle reprodutivo em Melipona marginata Lepeletier (Apidae, Melponinae). PhD thesis, IBUSP, Brazil

Kleinert-Giovannini A (1990) Interest conflit in colonies of Melipona marginata Lepeletier (Apidae, Meliponinae). In: Social Insects and the Environment (GK Veeresh, B Malik, CA Viraktamath, eds), Oxford \& IBH Publishing Co, UK

Kleinert AMP, Imperatriz-Fonseca VL (1994) Virgin queens refuges in colonies of Melipona marginata (Apidae, Meliponinae). Rev Bras Biol 54, 247-251

Michener CD (1946) Notes on the habits of some Panamanian stingless bees. J New York Ent Soc 56,179197 
Mota MHVB (1982) Estudo comparativo das glândulas abdominais relacionadas com o comportamento social em Apidae (Apinae e Meliponinae). MSc thesis, UNESP, Brazil

Mota MHVB (1988) Estudo comparativo das glândulas epidérmicas do abdômen dos meliponíneos (Apidae, Meliponinae). PhD thesis, UNESP, Brazil

Moure JS (1951) Notas sobre Meliponinae (Hymenoptera, Apoidea). Dusenia 2, 25-70

Moure JS (1961) A preliminary supra-specific classification of the Old World Meliponinae bees (Hymenoptera, Apoidea). Studia Entomologica 4, $181-242$

Moure JS, Nogueira-Neto P, Kerr WE (1958) Evolutionary problems among Meliponinae (Hymenoptera, Apidae). ProcX Int Cong Ent 2, 481-493

Nogueira-Neto $P$ (1951) Stingless bees and their study. Bee World 32, 73-76

Nogueira-Neto $P$ (1954) Notas bionômicas sobre meliponineos III Sobre a enxameagem. Arq Mus Nac 42, 419-451

Nogueira-Neto $P$ (1958) Rainhas prisioneiras. Chacaras Quintaes 97, 477

Oliveira MAC, Imperatriz-Fonseca VL (1973) Observações sobre o comportamento de uma colônia mista de Plebeia saiqui-Plebeia droryana (Hymenoptera, Apidae, Meliponinae). Cienc Cult 25, 460-462

Page RE Jr, Kerr WE (1990) The evolution of monandry and queen replacement in Melipona. Rev Bras Genet $13,209-229$

Pain J (1961) Sur la phérormone des reines d'abeilles et ses effects physiologiques. Ann Abeille 103

Peckolt T (1894) Ueber Brasilianische Bienen. Natur 43, 87-91, 223-226, 233-234

Ribeiro MF (1989) Estudos ecoetológicos em Frieseomelitta languida (Hymenoptera, Apidae, Meliponinae). MSc thesis, IBUSP, Brazil

Sakagami SF (1971) Ethosoziologischer Vergleich zwischen Honigbienen und stachellosen Bienen. Z Tierpsychol 28, 337-350
Sakagami SF (1982) Stingless bees. In: Social Insects (HD Hermann, ed), Academic Press, New York, 361 423

Silva DLN (1972) Considerações em torno de um caso de substituição de rainha em Plebeia (Plebeia) droryana. In: Homenagem a W.E.Kerr (C Cruz-Landim, ed), Ribeirão Preto, Brazil

Silva DLN (1977) Estudos bionômicos em colônias mistas de Meliponinae. Bol Zool Univ São Paulo 2, 7 108

Silva DLN, Zucchi PA, Kerr WE (1972) Biological and behavior aspects of the reproduction in some aspects of Melipona (Hymenoptera, Apoidea). Anim Behav 20, 123-132

Simões D (1974) Estudo sobre a regulação social em Nannotrigona (Scaptotrigona) postica Latreille com especial referência a aspectos comportamentais. MSc thesis. FMRP-USP, Brazil

Simões D, Bego LR (1979) Estudo da regulação social em Nannotrigona (Scaptotrigona) postica Latreille, em duas colônias (normal e com rainhas virgens) com especial referência ao polietismo etário (Hymenoptera, Apidae, Meliponinae). Bol Zool Univ $S$ Paulo 4, 89-98

Sommeijer MJ (1994) Reproduction strategies and feeding ecology of stingless bees in relation to environmental problems. Abstracts XII Congr Int IUSSI, Paris, 19

Terada Y (1974) Contribuição ao estudo da regulação social em Leurotrigona muelleri e Frieseomelitta varia. MSc thesis, USP, Ribeirão Preto, Brazil

Van Benthem FD, Imperatriz-Fonseca, VL, Velthuis, HHW (1995) Biology of the stingless bee Plebeia remota (Holmberg): observations and evolutionary implications. Insectes Soc 42, 71-87

Velthuis HHW, Sommeijer MJ (1991) Roles of morphogenetic hormones in caste polymorphism in stingless bees. In: Morphogenetic hormones of Arthropods (AP Gupta, ed), Rutgers Univ Press, NJ, 346-383

Zucchi R (1977) Aspectos etológicos-evolutivos da bionomia dos Meliponinae (Hymenoptera, Apidae). Livredocenz Thesis, Ribeirão Preto, Brazil 